\title{
TESTING THE EFFECTIVENESS OF BERYLLIUM-7 AS A TRACER OF THE MOVEMENT OF SEDIMENT OVER SHORT PERIODS ALONG A CAVE STREAM IN HIDDEN RIVER CAVE, KENTUCKY U.S.A.
}

\author{
Caroline A. Broderick ${ }^{1}$, Carol M. Wicks ${ }^{1, C}$, and Randall L. Paylor ${ }^{1}$
}

\begin{abstract}
A feasibility study using beryllium-7 $\left({ }^{7} \mathrm{Be}\right)$ as a tracer of the movement of sediment through a karstic basin over short timescales of 2 to 3 months was undertaken. If ${ }^{7} \mathrm{Be}$ is an effective tracer of sediment movement, then the average ${ }^{7} \mathrm{Be}$ activity measured on sediment collected from backwater facies after high-flow events would be higher than that measured after periods of low-flow conditions. To test this, sediment was collected along a cave stream in Hidden River Cave, Kentucky, U.S.A. At the most basic level, collected sediment had measureable ${ }^{7} \mathrm{Be}$ activities, so using ${ }^{7} \mathrm{Be}$ to track movement of sediment from the surface into karstic basins is a viable method. In addition, the measured ${ }^{7} \mathrm{Be}$ activities were higher after a period of rainfall and presumably high flow events $\left(>1 \mathrm{~d} \mathrm{~m}^{-1} \mathrm{~g}^{-1}\right)$ than after a period of relatively few rainfall events and presumably low-flow conditions $\left(0.16 \mathrm{~d} \mathrm{~m}^{-1} \mathrm{~g}^{-1}\right)$.
\end{abstract}

\section{Introduction}

This study uses isotopic dating of the naturally occurring isotope ${ }^{7} \mathrm{Be}\left(\mathrm{t}_{1 / 2}=53.3\right.$ days). Other isotopic tracers, such as cesium-137 ( $t_{1 / 2}=30.2$ years) and lead-210 ( $t_{1 / 2}=22.2$ years), which are used extensively for sediment tracing and budget studies (e.g., Blake et al., 2002), are not useful for short timescales that may be important for studies in karstic systems (Mahler and Lynch, 1999).

${ }^{7} \mathrm{Be}$ forms when low energy neutrons collide with oxygen and nitrogen atoms in the stratosphere (Brost et al., 1991; Junge, 1963). The newly created ${ }^{7} \mathrm{Be}$ atoms circulate in the atmosphere until the ${ }^{7} \mathrm{Be}$ atoms are scavenged by submicron particles that continue circulating in the stratosphere or lower atmosphere as the attached ${ }^{7} \mathrm{Be}$ radioactively decays. Approximately $59 \%$ of ${ }^{7} \mathrm{Be}$ atoms decay in the atmosphere, the other $41 \%$ of ${ }^{7} \mathrm{Be}$ atoms fall to earth's surface (Brost et al., 1991). Of the ${ }^{7} \mathrm{Be}$ that reaches earth, $94 \%$ falls in precipitation and $6 \%$ falls as dry deposition.

${ }^{7} \mathrm{Be}$ decays into ${ }^{7} \mathrm{Li}$ through orbital-electron capture (Walsh, 2009) when a proton from the nucleus reacts with one of the electrons from the $\mathrm{K}$ electron cloud $\left(\mathrm{e}_{\mathrm{k}}\right)$ and releases a neutrino $(v)$ and gamma rays as described by Hans (2001): ${ }^{7} \mathrm{Be}+\mathrm{e}_{\mathrm{k}} \rightarrow{ }^{7} \mathrm{Li}+\mathrm{v}$. Thus, ${ }^{7} \mathrm{Be}$ activity is measured by counting gamma emission that is directly related to decay of ${ }^{7} \mathrm{Be}$ (Corbett et al., 2007; Fabre, 2012).

On the surface of the earth, the ${ }^{7} \mathrm{Be}$ absorbs preferentially on the surface of aluminosilicate particles in soils and sediment. Sediment with measurable ${ }^{7} \mathrm{Be}$ activity indicates that the sediment was exposed to atmospheric deposition, either dry or wet, within three to five half-lives (160 to 270 days; Rotondo and Bentley, 2003). Thus, ${ }^{7} B e$ has been used in studies of transport of fine-grained sediment in rivers (Sommerfield et al., 1999), Bonniwell et al., 1999) and the erosion of soils (Blake et al., 1999) and in sediment-budget studies (Rotondo and Bentley, 2003; Corbett et al., 2007). Other studies have combined ${ }^{7} \mathrm{Be},{ }^{137} \mathrm{Cs}$, and ${ }^{210} \mathrm{~Pb}$ for investigation of land degradation and sediment residence times in catchment systems (Brost et al., 1991; Evrard, et al., 2010; Bentley et al., 2014). These cited works provide an understanding of source, transport, and deposition of fine-grained sediments during recharge events. All of those studies investigated transport of sediment over short time scales.

Allochthonous sediment is brought into caves as soil eroded from the surface or as sediment transported into the cave streams by sinking streams during high-flow events (Livesay and McGrain, 1962). Bosch and White (2007) describe the transport of allochthonous sediment into and through karstic basins and the resultant lithofacies: that are diamicton (unsorted, unstratified sediment), thalweg (armor layer), channel (well sorted), and slackwater (carried as suspended load). Previous studies have shown that nearly all of the sediment transport through karstic basins occurs during or immediately following high-flow events (Mahler and Lynch, 1999; Groves and Meiman, 2005). Mahler et al. (1998) state that the best way to calculate the residence times of sediment in karstic basins is through the use of particle tracing. Thus, there is a need for a sediment tracer that tracks sediment movement over short time scales. This study assesses the feasibility of using ${ }^{7} \mathrm{Be}$ as a tracer of the movement of sediment into and through karstic basins with a focus on sediment transported as suspended load and deposited as slackwater facies.

\footnotetext{
1 Department of Geology and Geophysics, Louisiana State University, Baton Rouge LA 70803, USA

c Corresponding Author: cwicks@lsu.edu
} 


\section{Description of Study Site}

Hidden River Cave (HRC) is within the $900 \mathrm{~km}^{2}$ Gorin Mill basin in Kentucky, U.S.A. (Fig. 1). The area is part of the Mammoth Cave region and is located about seven miles due east of the National Park boundary. The Gorin Mill basin is characterized by isolated hills (knobs) rising at most $40 \mathrm{~m}$ above a karst plain that is pockmarked with numerous shallow (less than $10 \mathrm{~m}$ deep) sinkholes. There is no discharge measuring station within the Gorin Mill basin. There are three precipitation stations adjacent to the Gorin Mill basin.

HRC is a fluviokarst system. The humanly accessible entrance to HRC is located in the town of Horse Cave (37'10'34" N, 8554'22" W; Livesay and McGrain, 1962). Water enters the cave as sinking streams in its distal portions (Toomey and Olson, 2008). The cave stream flows along conduits, past the humanly accessible entrance, and continues downstream in the subsurface. Sampling sites were located near to and in the upstream direction from the human entrance.

\section{Field Methods}

Samples of sediment from within HRC were collected on April 15, April 29 to May 1, and on May 20 and 21, 2014. These samples were collected at locations near the waterline of the cave stream by using a thin-bladed spatula to carefully scrape the topmost $2 \mathrm{~cm}$ of sediment into petri dishes. The area scraped was less than a 100 $\mathrm{cm}^{2}$. All samples were brought back to Louisiana State University's Department of Geology and Geophysics for determination of ${ }^{7} \mathrm{Be}$ activity, granulometry, and mineralogical composition. Scraping from a limited area to a fixed depth limited the volume and mass of sediment collected. Thus granulometry and mineralogical analyses were limited to a subset of collected samples, whereas, the activity of ${ }^{7} \mathrm{Be}$ was determined for each sample collected.

\section{Laboratory Methods}

Upon return to LSU and following the method in Keller et al. (2016), the samples were dried in an oven at $60^{\circ} \mathrm{C}$ for a minimum of twelve hours, visible organics and large pebbles were removed by hand, and then the remaining sediment was ground. For each sample, the ${ }^{7} \mathrm{Be}$ activity in disintegrations per minute per gram $\left(\mathrm{d} \mathrm{m}^{-1} \mathrm{~g}^{-1}\right)$ was determined using a Canberra Broad Energy Germanium Detector (BEGE) with processing handled using Canberry GenieData Software. Samples were held in the BEGE detector for a minimum of twenty-four hours so that significant spikes in the gamma-ray spectrum could be identified at the signature $477 \mathrm{keV}$ energy of the decay. The measurements were corrected to account for the decay that occurred since the date of sample collection.

Granulometric analyses were performed using a Beckman-Coulter LS 13320 laser diffractor. The duration of the laser diffraction runs was five minutes. Pre-processing included sieving the previously dried sample through a $1 \mu \mathrm{m}$ sieve, rinsing the resultant sample with hydrogen peroxide $\left(0.05 \mathrm{v} / \mathrm{v} \mathrm{H}_{2} \mathrm{O}_{2}\right)$, and deflocculating the sample with $10 \mathrm{~mL}$ of $0.05 \%$ sodium phosphate $\left(\mathrm{NaH}_{2} \mathrm{PO}_{4}\right)$. After pre-processing, each sample was analyzed with the Beckman Coulter laser diffractor for five minutes to collect

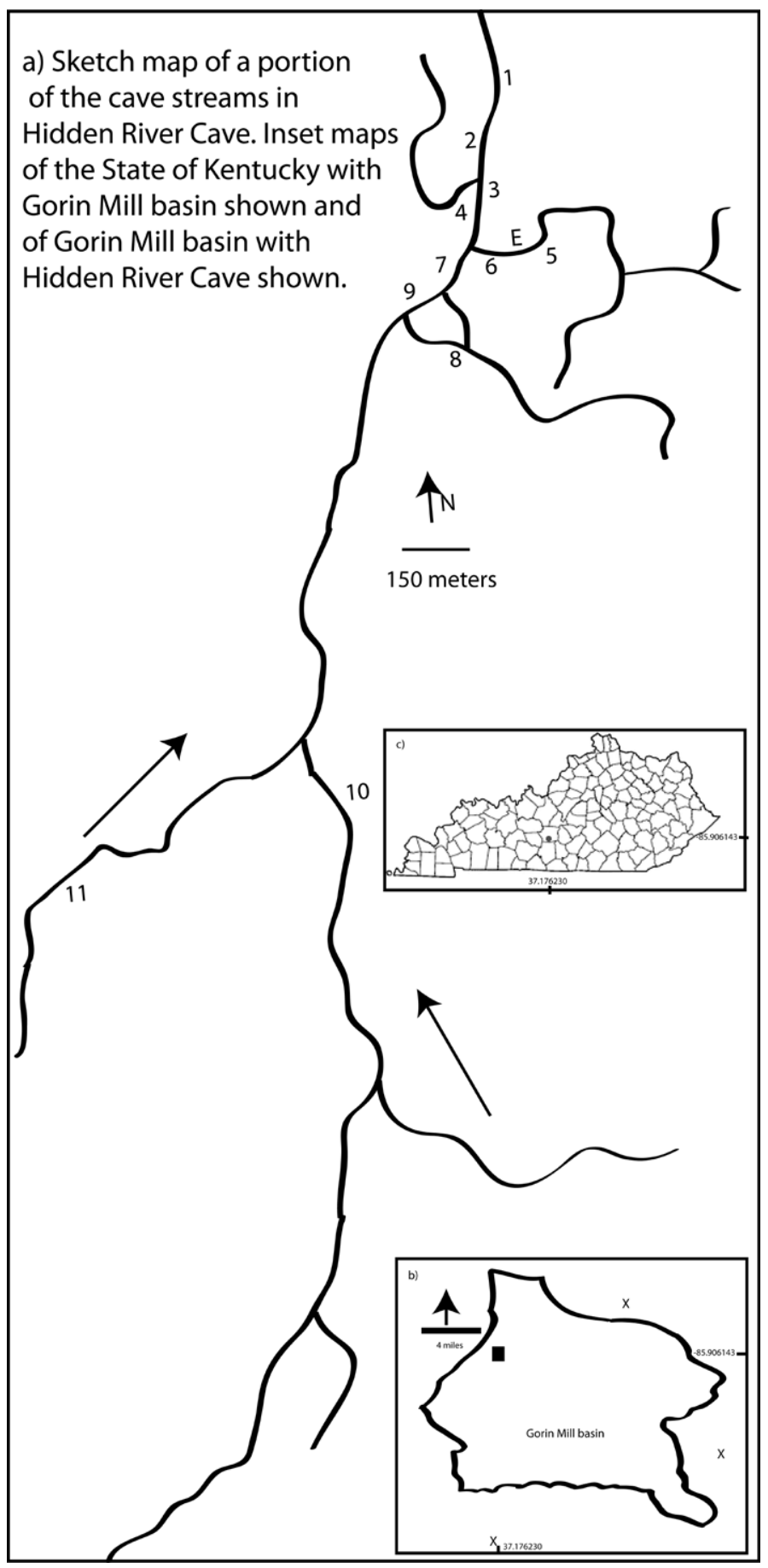

Figure 1. Simplified map showing a portion of the streams in Hidden River Cave that were sampled. The entrance (E), sampling sites (111 ), and flow direction (arrows) are shown (panel a; modified from West, 2013). Location of Hidden River Cave (black square) and nearby precipitation records $(x)$ of the Gorin Mill basin are shown (panel b; Kentucky Geological Society). Location of Gorin Mil basin within the State of Kentucky (panel c). 
the mean and the range of grain sizes.

Bulk mineralogical analysis was performed using an Empyrean x-ray diffractrometer. Pre-processing included sieving the previously dried samples using a $30 \mu \mathrm{m}$ sieve, mixing the sample with $10 \mathrm{~mL}$ of ethanol, processing in the micronizer and centrifuge, and drying overnight at $60^{\circ} \mathrm{C}$ (Cook et al., 1975). After pre-processing, samples were analyzed on the XRD by the Reflective Transmission Spinner with the automatic divergence slit between $4^{\circ}$ and $70^{\circ}$ scans. The scans were done at 0.02 degree increments for 60 seconds. Data were processed through Jade software following standard techniques (Griffin, 1971).

\section{Results}

The mineralogical composition of the sediment was $84-88 \%$ quartz, $8-12 \%$ aluminosilicate clays, and approximately $2 \%$ carbonate (Table 1). The mean grain size range from 48 to $77 \mu \mathrm{m}$. The ${ }^{7} \mathrm{Be}$ activity ranged from 0.10 to 1.33 $d \mathrm{~m}^{-1} \mathrm{~g}^{-1}$.

As there is no discharge recording location within the Gorin Mill basin, we have had to rely on data collected at nearby locations. This adds uncertainty to our study, because we had to rely on precipitation records to guide our understanding of the timing of low- and high-flow events. Side-by-side duplicate sediment samples were collected on May 29. The ${ }^{7} \mathrm{Be}$ activities of the duplicates were below analytical detection limit; therefore we could not determine variation at the scale at which we collected samples $\left(100 \mathrm{~cm}^{2}\right)$.

\section{Discussion and Summary}

Sediment with measurable ${ }^{7} \mathrm{Be}$ activity indicates that the sediment was exposed to atmospheric deposition (either dry or wet) within three to five half-lives (160 to 270 days; Rotondo and Bentley, 2003). As sediment collected from within Hidden River Cave had measurable ${ }^{7} \mathrm{Be}$ activities (Table 1), this sediment had been exposed to atmospheric deposition in the previous 270 days, and that sediment had been at the land surface and transported into HRC within the previous 270 days. This shows that ${ }^{7} \mathrm{Be}$ can be used as a tracer of sediment movement in karstic basins.

There were numerous rainfall events during April and May 2014, including two large events: one occurred on April 28 and the other on May 14 (Fig. 2). These large precipitation events likely resulted in high-flow events that transported

Table 1. ${ }^{7} \mathrm{Be}$ activity and mineralogical composition of the sediment.

\begin{tabular}{cccccccc}
\hline Collection Date & $\begin{array}{c}\text { Location } \\
\text { Sampled }\end{array}$ & $\begin{array}{c}\text { Be-7 Activity, } \\
\mathbf{d p m ~ g}^{-1}\end{array}$ & Quartz, \% & $\begin{array}{c}\text { Alumino-Silicate } \\
\text { Clay, } \%\end{array}$ & Carbonate, \% & Grain Size, $\mu m$ \\
\hline $4 / 15 / 2014$ & 3 & 0.1 & $\ldots$ & $\ldots$ & $\ldots$ & $\ldots$ \\
$4 / 29 / 2014$ & 2,5 & $0.28 \pm 0.33$ & $85 \pm 3.5$ & $11 \pm 2.7$ & $1.9 \pm 0.16$ & $48 \pm 47$ \\
$4 / 30 / 2014$ & 6 & 0.22 & $\ldots$ & $\ldots$ & $\ldots$ & $\ldots$ \\
$5 / 1 / 2014$ & 9 & 0.91 & $\ldots$ & $\ldots$ & $1.8 \pm 0.3$ & $73 \pm 45$ \\
$5 / 20 / 2014$ & $1,3,4,7$ & $0.90 \pm 0.56$ & $88 \pm 3.3$ & $8.4 \pm 2.7$ & $2 \pm 0.7$ & $77 \pm 58$ \\
$5 / 21 / 2014$ & $8,9,10,10$ & $1.33 \pm 1.89$ & $84 \pm 3.1$ & $12 \pm 3.6$ & $\ldots$ & $\ldots$ \\
\hline
\end{tabular}

suspended sediment into HRC. The measured ${ }^{7} \mathrm{Be}$ activity in slackwater facies, ranging from 0.22 to $1.3 \mathrm{~d} \mathrm{~m}^{-1} \mathrm{~g}^{-1}$, was higher after the two large precipitation events compared to that measured prior to either large precipitation event $\left(0.16 \mathrm{~d} \mathrm{~m}^{-1} \mathrm{~g}^{-1}\right)$. Given our null hypothesis that the measured ${ }^{7} \mathrm{Be}$ activity prior to and after high-flow events would be equal and based on a two-sided t-test analysis, the null hypothesis was rejected. This supports our understanding of suspended sediment being delivered into the cave stream by losing streams and deposited as slackwater facies (Bosch and White, 2007). This also lends evidence for the need for tracers to track movement of sediment over short time-scales in karstic basins (Mahler and Lynch, 1999).

Bentley et al. (2014) have reported a relation between ${ }^{7} \mathrm{Be}$ activity and grain size and between ${ }^{7} \mathrm{Be}$ activity and mineralogical composition of the sediment. The sediment

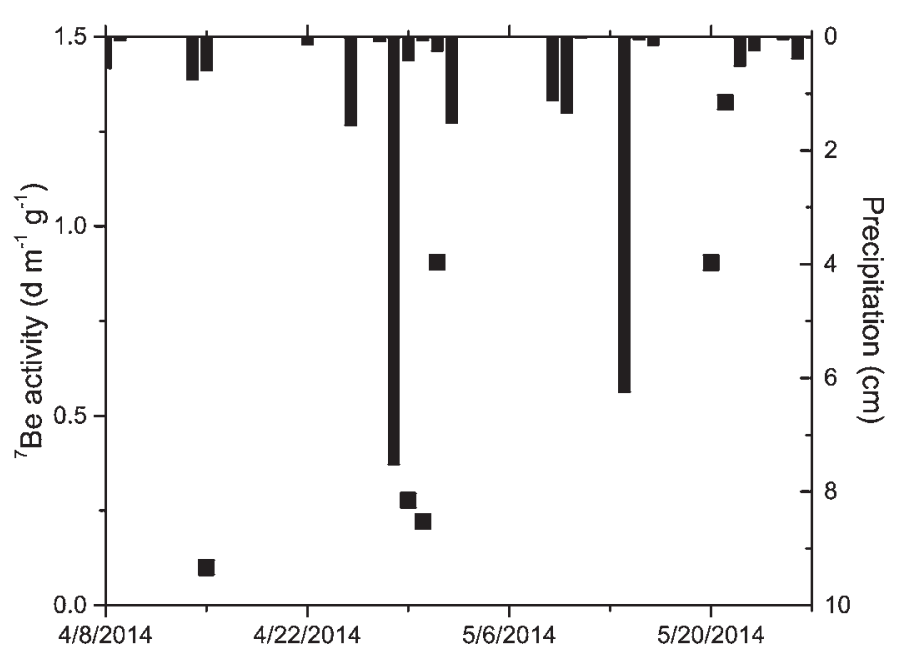

Figure 2. Precipitation (bars) and ${ }^{7} \mathrm{Be}$ activity (closed circles) as a function of time. 
A

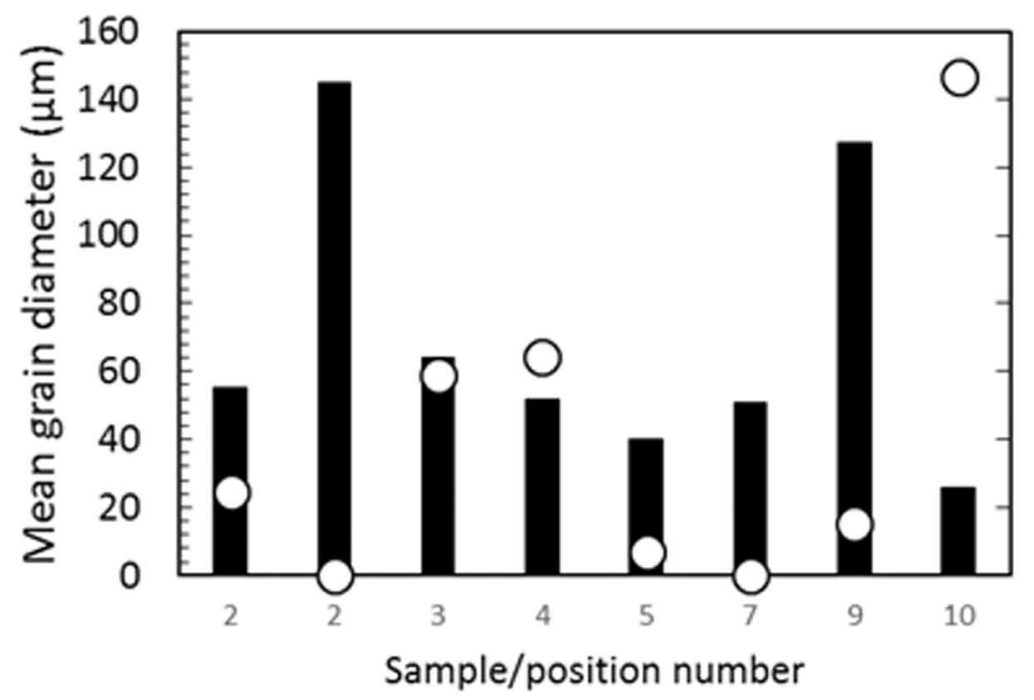

4.0

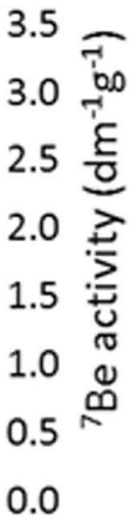

B

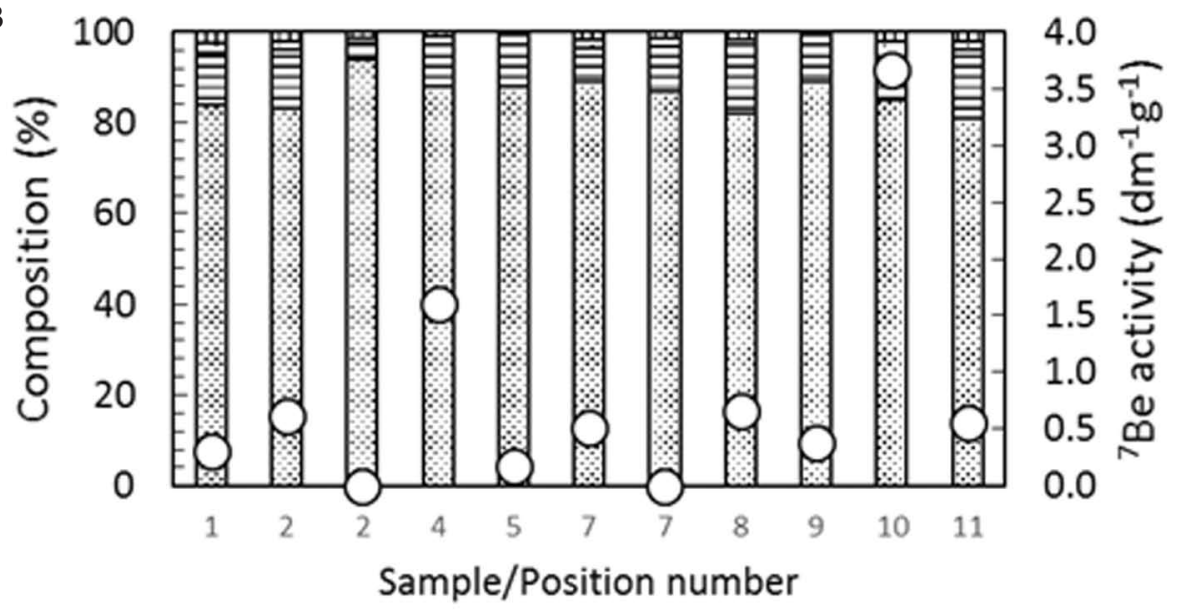

囚 Quartz 日Clay ๑Carbonate $\mathbf{0}$ Other OBe-7

Figure 3. ${ }^{7} \mathrm{Be}$ activity (closed circles) plotted against particle size (bars; panel A) and against mineralogical composition (bars; panel B).

was fine-grained and primarily aluminosilicate in composition. We found no relation between the ${ }^{7} \mathrm{Be}$ activity and the mean, mode, or median grain size of the coarser-grained sediment collected in this study or between the ${ }^{7} \mathrm{Be}$ activity and mineralogical composition (percentage quartz, calcite, or clay) of the calcite-rich sediment collected in this study (Fig. 3). In all cases, correlation coefficients were less than 0.25 and the F-significance levels were greater than 0.15 . The coarser and quartz-rich sediment collected in this study might have masked the relations shown by Bentley et al. (2014), who sampled a finer-grained, alumno-silcate rich sediment.

In summary, the goal of this feasibility study was to determine if ${ }^{7} \mathrm{Be}$ was a viable tracer of sediment transported into karstic basins as suspended load and deposited as slackwater facies. The data show that ${ }^{7} \mathrm{Be}$ is a useful tracer. This study was of limited scope due to the small volume of sample that could be scrapped from along the cave stream. In future work, researchers should plan to sample a larger area to collect more grams per location without sampling more than 2 centimeters of depth. Sampling could also be timed to coincide with months of low flow for better control on background activities and high flow for better results on storm-event signals. Even with these limitations, the ${ }^{7} \mathrm{Be}$ method used in this investigation will aid researchers who study movement of sediment in karstic basins.

\section{Acknowledgements}

Funding from the National Science Foundation to CMW is greatly appreciated (EAR1141745). We also thank Dr. Samuel Bentley for maintaining the BEGE detectors and allowing the use of the BEGE detector and software in this research. 


\section{References}

Bentley, S.J. Sr., Swales, A., Pyenson, B., and Dawe, J., 2014, Sedimentation, bioturbation, and sedimentary fabric evolution on a modern mesotidal mudflat: A multi-tracer study of processes, rates, and scales: Estuarine, Coastal and Shelf Science, v. 141, 58-68. https://doi. org/10.1016/j.ecss.2014.02.004.

Blake, W.H., Walling, D.E., He, Q., 1999, Fallout beryllium-7 as a tracer in soil erosion investigations: Applied Radiation and Isotopes, v. 51, 599-605. https://doi.org/10.1016/S0969-8043(99)00086-X.

Blake, W.H., Walling, D.E., and He, Q., 2002, Using cosmogenic beryllium-7 as a tracer in sediment budget investigations: Geografiska Annaler, v. 84 A, no.2, 89-102. https://doi.org/10.1111/1468-0459.00163.

Bonniwell, E.C., Matisoff, G., and Whiting, P.J., 1999, Determining the times and distances of particle transit in a mountain stream using fallout radionuclides: Geomorphology, v. 27, 75-92. https://doi.org/10.1016/S0169-555X(98)00091-9.

Bosch, R.F., and White, W.B., 2007, Lithofacies and transport of clastic sediments in karstic aquifers, in Sasowsky, I.D., and Mylroie, J., eds., Studies of Cave Sediments: Physical and Chemical Records of Paleoclimate: Springer, $328 \mathrm{p}$.

Brost, R.A., Feichter, J., and Heimann, M., 1991, Three-dimensional simulation of ${ }^{7}$ Be in a global climate model: Journal of Geophysical Research, v. 96, 22423-22445. https://doi.org/10.1029/91JD02283.

Cook, H.E., Johnson, P.D., Matti, J.C., and Zemmels, I., 1975, Methods of sample preparation and X-ray diffraction data analysis: Initial Reports of the Deep Sea Drilling Project, v. 28, p. 999-1007. https://doi.org/10.2973/dsdp.proc.28.app4.1975.

Corbett, D.R., Dail, M., and McKee, B., 2007, High-frequency time-series of the dynamic sedimentation processes on the western shelf of the Mississippi River Delta: Continental Shelf Research, v. 27, p. 1600-1615. https://doi.org/10.1016/j.csr.2007.01.025.

Evrard, O., Némery, J., Gratiot, N., Duvert, C., Ayrault, S., Lefèvre, I., Poulenard, J., Prat, C., Bonté, P., and Esteves, M., 2010, Sediment dynamics during the rainy season in tropical highland catchments of central Mexico using fallout radionuclides: Geomorphology, v. 124, p. $42-54$. https://doi.org/10.1016/j.geomorph.2010.08.007.

Fabre, J.B., 2012, Sediment flux and fate for a large scale diversion: the 2011 Mississippi River flood, the Bonnet Carré Spillway, and the implications for coastal restoration in south Louisiana [MS thesis]. Baton Rouge, Louisiana State University. 51 p.

Griffin, G.M., 1971, Interpretation of X-ray diffraction data, in Carver, R.E., Procedures in Sedimentary Petrology: New York: Wiley-Interscience, p. 541-569.

Groves, C., and Meiman, J., 2005, Weathering, geomorphic work, and karst landscape evolution in the Cave City groundwater basin, Mammoth Cave, Kentucky: Geomorphology, v. 67, 115-126. https://doi.org/10.1016/j.geomorph.2004.07.008.

Hans, H.S., 2001, Beta decay, in Hans, H.S., Nuclear Physics: Experimental and Theoretical: Daryaganj, New Delhi, New Age International, p. 307-369.

Junge, C.E., 1963, Air Chemistry and Radioactivity: New York, Academic Press, 382 p.

Keller, G., Bentley, S.J., Georgiou, I.Y., Maloney, J., Miner, M.D., and Xu, Kehui, 2016, River-plume sedimentation and 210Pb/7Be seabed delivery on the Mississippi River delta front: Geo-Marine Letters, 14 p. https://doi.org/10.1007/s00367-016-0476-0.

Livesay, A., and McGrain, P., 1962, Geology of the Mammoth Cave National Park Area: Lexington, Kentucky, College of Arts and Sciences, University of Kentucky special publication 7. 40 p.

Mahler, B.J., and Lynch, F.L., 1999, Muddy waters: temporal variation in sediment discharging from a karst spring: Journal of Hydrology, v. 214, 165-178. https://doi.org/10.1016/S0022-1694(98)00287-X.

Mahler, B.J., Bennett, P.C., and Zimmerman, M., 1998, Lanthanide-labeled clay: a new method for tracing sediment transport in karst: Ground Water, v. 36, no. 5, 835-843. https://doi.org/10.1111/j.1745-6584.1998.tb02202.x.

Rotondo, K.A., and Bentley, S.J., 2003, Deposition and resuspension of fluid mud on the western Louisiana inner shelf: Gulf Coast Association of Geological Societies Transactions, v. 53, 722-731.

Sommerfield, C.K., Nittrouer, C.A., and Alexander, C.R., 1999, ${ }^{7}$ Be as a tracer of flood sedimentation on the northern California continental margin: Continental Shelf Research, v. 19, p. 335-361. https://doi.org/10.1016/S0278-4343(98)00090-9.

Toomey, R.S., and Olson, R., 2008, Field Trip Guide, Mammoth Cave National Park Tour: Mammoth Cave, KY.

Walsh, K.A., 2009, Introduction, in Walsh, K.A., Beryllium Chemistry and Processing: Materials Park, OH, The Materials Information Society, p. $1-4$. 